\title{
Article
}

\section{Sports mega-events - three sites of contemporary political contestation}

\author{
Horne, John David
}

Available at http://clok.uclan.ac.uk/13576/

Horne, John David ORCID: 0000-0003-4389-8204 (2017) Sports mega-events three sites of contemporary political contestation. Sport in Society, 20 (3). pp. 328-340. ISSN 1743-0437

It is advisable to refer to the publisher's version if you intend to cite from the work. http://dx.doi.org/10.1080/17430437.2015.1088721

For more information about UCLan's research in this area go to

http://www.uclan.ac.uk/researchgroups/ and search for <name of research Group>.

For information about Research generally at UCLan please go to http://www.uclan.ac.uk/research/

All outputs in CLoK are protected by Intellectual Property Rights law, including Copyright law. Copyright, IPR and Moral Rights for the works on this site are retained by the individual authors and/or other copyright owners. Terms and conditions for use of this material are defined in the policies page.

\section{CLoK}

Central Lancashire online Knowledge www.clok.uclan.ac.uk

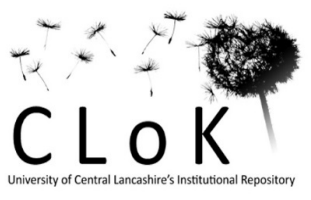


Sports Mega-Events - Three Sites of Contemporary Political Contestation

John Horne

Professor John Horne, FAcSS, PhD

School of Sport and Wellbeing

University of Central Lancashire

Preston, PR1 2HE U.K.

jdhorne@uclan.ac.uk

v2

6,648 words (inclusive - of abstract, figures and references)

N.B. version accepted for Sport in Society (minus proof changes) 


\title{
Sports Mega-Events - Three Sites of Contemporary Political Contestation
}

\begin{abstract}
This article discusses the contemporary politics of sports mega-events, involving the Olympic Games and FIFA Men's Football World Cup Finals as well as other lower 'order' sports megas, taking two main forms: the promotional and the protest. There is a politics in, and a politics of, sports mega-events. The former focuses on the internal politics of the organising bodies, such as the IOC and FIFA. This form of politics has been written about elsewhere and hence there is no detailed discussion in this article about it. Instead this article offers a brief discussion of the range and number of sports mega-events since 2000, an assessment of the contemporary politics of sports mega-events, a focus on three main sites of political contestation - rights, legacy and labour, and finally it offers conclusions about research into the politics of sports mega-events.
\end{abstract}




\section{Sports Mega-Events - Three Sites of Contemporary Political Contestation}

\section{Introduction}

This article discusses the contemporary politics of sports mega-events, involving the Olympic Games and FIFA Men's Football World Cup Finals, as well as other lower 'order' sports megas (Black 2014). For the past 50 years - roughly since the Tokyo Summer Olympics of 1964 - sports mega-events have been caught up in symbolic politics taking two main forms. Firstly, there are the promotional opportunities offered by them to enhance reputations - by competing with other cities and nations, winning the right to stage them and actually hosting them. This form of politics is sometimes referred to as the exercise of 'soft power' or public diplomacy, as nations, and increasingly cities, have sought to develop their place in the modern world and establish what has been referred to as 'brand identity' (Anholt 2008; Grix and Houlihan 2013). Refusing to participate in a sports mega-event through different forms of boycott can be seen as a form of negative public diplomacy.

Secondly, there is the opportunity for non-state actors and social movements to protest about a perceived social injustice by 'seizing the platform' offered by sports mega-events watched by hundreds of millions of people and reported on by most of the world's media (Price 2008). The next Summer Olympics after Tokyo 1964, staged in Mexico City in 1968, saw the best example of this in the form of the famous 'salute' by John Carlos and Tommie Smith in support of the Olympic Project for Human Rights (Hartmann 2003; Henderson 2010). More recently evictions of low income communities from housing to make way for mega-event related projects and other infringements of human rights have also become part of the Olympic and FIFA Men's Football World Cup narrative (COHRE 2008). 
This article is structured in four sections: a brief discussion of the range and number of sports mega-events since 2000; an assessment of the contemporary politics of sports mega-events; a focus on three main sites of political contestation - rights, legacy and labour; and finally it offers conclusions about research into the politics of sports mega-events.

\section{Defining the Field}

Definitions of mega-events vary across different theoretical understandings and disciplines, e.g. economics, geography, political science, urban planning, as well as sociology. In lieu of an agreed definition, Roche (2000) offers a way to understand the features of mega-events sociologically that has been adopted by many others and is used here - 'large-scale cultural (including commercial and sporting) events, which have a dramatic character, mass popular appeal and international significance' (Roche 2000, 1). These characteristics go some way to explain the allure or attraction of sports mega-events to potential host cities or nations. For individuals sports mega-events offer the promise of a festival of sport, with emotional moments, shaping personal (life) time horizons. Two features of contemporary sports megaevents are first then, that they are deemed to have highly significant social, political, economic and ideological consequences for the host city, region or nation in which they occur, and second, that they will attract considerable media coverage. By this definition, therefore, an unmediated mega-event would be a contradiction in terms, and for this reason the globally mediated sports genre of mega-event has tended to supplant other forms of 'mega', such as World's Fairs or Expos, although these latter do continue to be enthusiastically hosted and attract substantial numbers of visitors.

Additionally we need to consider the existence of first, second, third and even lower orders or tiers of (sports) mega-events according to their reach and range, cost and size (Black 2014; 
but also see Müller (2015) who suggests an alternative scheme that attempts to avoid a "'once and for all"" classification of specific events). For my purposes in this chapter I will refer to the following as amongst the most significant sports mega-events: Tier 1 - Summer Olympic Games and FIFA Men's Football World Cup; Tier 2 - Winter Olympic Games and UEFA Men's EURO Football championship; Tier 3 - Commonwealth Games and Pan American Games (see Figure 1).

Insert Figure 1 Sports Mega-Events 2000-2023 Here

Since 2000 there have been 23 editions of these six sports mega-events and there are 13 to come before 2024. Three hosts are still to be decided (at the time of writing in May 2015) and the Commonwealth Games and the Winter Olympics have been experiencing difficulties finding hosts recently. Nonetheless the Winter Olympics in 2010 attracted 2,600 competitors, the Commonwealth Games in Glasgow in 2014 featured 7,300 sport teams members, and it is predicted that the Pan Americans in Toronto in 2015 will see 7,700 competitors. Flyvbjerg (2014) suggests strictly speaking we should distinguish between 'mega' (million), 'giga' (billion), and 'tera' (trillion) dollar (USD) -projects depending on their scale. Certainly the biggest two sports mega-events routinely now cost several billions of dollars to stage and might justifiably be called 'giga' events. The sports mega-events staged by members of the BRICS alliance (Brazil, Russia, India, China and South Africa) since 2000 have also pushed the costs of staging events upwards (see Zimbalist 2015).

Black (2014) argues convincingly that we should look at megas as a means to fund development processes and objectives. In doing so they will inevitably benefit certain interests, not all interests. With respect to 'second-order' megas, they are attractive to second tier locales in the globalized world for two main reasons. First, the more 'relevance challenged' mega-events can offer the only realistic means of pursuing event-centred 
development for certain urban areas. Some places can never realistically aspire to host an Olympic Games or host the FIFA World Cup finals. This was found out by Birmingham and Manchester in England as three bids in the 1980s and 1990s failed to attract enough attention from IOC members. Today this also applies to cities such as Glasgow in Scotland, which hosted the Commonwealth Games in 2014, and Edmonton (Canada) that was in competition with Durban (South Africa) to host the 2022 edition of the Commonwealth Games until the city withdrew citing economic reasons. Second, lower order mega-events can act as 'springboards' for cities to go on to bid to host first order mega-events. This was the strategy that the municipality of Rio de Janeiro took, to first host a smaller scale event (the Pan Americans in 2007) and then bid to host the summer Olympics. It is thought that if Durban is successful with its bid to host the Commonwealth Games in 2022, which now looks highly likely as it is the sole candidate, that this might be used to launch a bid to host the Summer Olympics in 2024 or 2028 . Thus it is that even the process of bidding to host a sports megaevent can be seen as full of political calculation.

There is a politics in, and a politics of, sports mega-events. The former focuses on the internal politics of the organising bodies, such as the IOC and FIFA. This form of politics is dealt with elsewhere (e.g. see Tomlinson 2014) and hence there is no detailed discussion in this article about, for example, the controversy over potential corruption in the bidding process in the selection of hosts for recent and future FIFA men's football World Cups (Conn 2015). The external politics of sports mega-events, which this paper deals with, relates to corporate interests and global forces in combination with, or confrontation with, local interests, and it is to this that we now turn. 


\section{Contemporary Politics}

It is important to realize that the politics of each and every sports mega-event is conjunctural - that means that it will be affected by different political circumstances at local, national, regional and global scales at different times and places. Nonetheless since the 1970 s there has been concern about 'gigantism' and 'white elephants' in the Olympics - the growth in scale of the events on one hand and the potential to build facilities and stadia that will be more costly to use and maintain than they are worth on the other. Economists and other social scientists have assessed sports mega-events in terms of their costs and benefits (Preuss 2004; Whitson and Horne 2006). Flyvbjerg (2014) suggests that an iron law of mega projects, including sports mega-events, is that they will be 'over budget, over time, over and over again'. Whether this is a constant or not it is certainly the case that most sports mega-events since the 1970 s have attracted political controversy.

Horne (2007, 86-91) identified a number of 'known unknowns' with respect to sports megaevents that have remained part of the political debate about sports mega-events. These include: the emphasis on consumption-based development as opposed to social redistribution with respect to the goals of hosting sports mega-events; urban regeneration that often leads to 'gentrification' of specific areas being regenerated; the displacement (and subsequent 'replacement') of poor and less powerful communities of people; the use of (often quite extensive) public sector funds to enhance private corporate sector gain; the local host sites and spaces benefitting global flows of capital, trade and finance; the spatial concentration of the impact of the event; the impacts on employment of hosting sports mega-events - and the duration of its impact; the impact on tourism flows never being near what is predicted by sports mega-event boosters mainly because of the displacement of non-sport tourists by the 
sport-event tourists; the way in which boosters have to resort to the manufacturing of the consent of local and national publics to get them on their side about staging the event; and the growth of opposition event coalitions as a result of some or all of these developments.

As mentioned earlier, symbolic politics - the promotional politics of promotional culture via public diplomacy, 'soft power' and/ or propaganda - are fundamental features of the contemporary politics of sports mega-events. Whether competing with other cities or nations to host an event, winning the right to do so, or actually hosting an event, the potential for symbolic power plays, or pitfalls, are real. All such exercises in promotional politics - nation branding, city branding, image alteration - run the danger of heightening reputational risk to the bidders (and eventual hosts) involved. According to the 2014 Anholt-GfK survey of national image, rather than boost Brazil's reputation in the world, hosting the 2014 World Cup Finals saw the country lose ground in the rankings whilst World Cup winners Germany knocked the USA off the top spot after 5 years (Anholt-GfK Roper 2014; Garcia 2014). Another aspect of political controversy since '9/11' (in 2001), and that stretches further back to the 'Munich' terrorist attack (in 1972), has been the relationship between the staging of sports mega-events and the growth of the security state. Societies have seen a continuing transformation of surveillance capabilities as the supposed threat of terrorist attack has grown. Sports mega-events have offered opportunities for new security equipment and procedures and surveillance operations to be trialled. As these three features - costs, reputational risk and security - have developed so too have other related sites of contestation, and some of these are identified in Figure 2.

Insert Figure 2 Sports Mega-Events and Contentious Issues Here 


\section{Three Sites of Contestation}

According to the late sociologist and criminologist Stanley Cohen $(2001,51)$ denial is 'the maintenance of social worlds in which an undesirable situation (event, condition, phenomenon) is unrecognised, ignored or made to seem normal'. Without the opposite of denial, acknowledgement, it is impossible to reach a situation of reconciliation between two or more opposing groups. With mega-event organizers and their representatives we do not often get acknowledgement of problematic situations, but usually denials. I now discuss in brief the politics of rights, legacy and labour in relation to sports mega-events, which have been acknowledged by some but not given the focus that they deserve until now (Giulianotti et al (2014) identified a 'politics of mobility' at the London 2012 Olympics but this is not considered in detail here).

\section{Rights}

Worden $(2015,1)$ identified five main human rights abuses have been apparent at recent and future sports mega-events:

1. The forced evictions of citizens without due process or compensation;

2. The abuse and exploitation of migrant workers;

3. The silencing of civil society and rights activists;

4. Threats, intimidation and arrest of journalists; and

5. Discrimination within nations competing to host or simply competing at the megaevents.

After Athens hosted the Summer Olympic Games in 2004, and with Beijing the next host, Jacques Rogge, then President of the International Olympic Committee (IOC), made the 
comment that 'The IOC is always in favour of maximum application of human rights...But it is not up to the IOC to monitor human rights' (cited in Kelso 2004). Nonetheless the build up to Beijing 2008 over the next four years saw an unprecedented focus by campaigners on human rights. Seeking to use the first Olympics in China to highlight human rights abuses the official torch relay was subverted and the Centre on Housing Rights and Evictions (COHRE) in Geneva published a dossier itemizing the displacements of hundreds of thousands of people to make way for the games (on the torch relay see Horne and Whannel 2010; COHRE 2008).

Narratives associated with hosting mega-events, and the Summer Olympic Games in particular, in East Asia and developing economies have included the following: that it provides an opportunity to catch up or modernize, an opportunity to challenge (Western) modernity, and an opportunity to project distinctive forms of hybrid or hyper-modernity. Whether in the form of overt politics, protest, or promotion, hosting a sports 'mega' event provides an opportunity for power plays by states, civic authorities, and groups for and against the event. Attempts to hijack the torch relay before Beijing 2008 actually provoked a nationalist response, when previously the Olympics were being promoted as an internationalising event. The Western media tended to portray the events of London, Paris and San Francisco as peaceful protests against a repressive regime and a military crackdown. The Chinese media eventually responded by considering the events as violent acts against innocent people (especially the disabled 'heroine' of Paris, Jin Jing) requiring the restoration of order and stability (Horne and Whannel 2010). In this way, different actors sought to impose their frames of reference on the situation.

The prominence of rights discourse remains the case for other mega-events that have taken place since 2008 in different parts of the world. When thousands of Brazilians took to the streets during the Confederations Cup in June 2013, FIFA President Sepp Blatter said on 
national television that 'I can understand people are not happy but they should not use football to make their demands heard' (cited in Watts 2013). Yet symbolic transformations of urban environments to fit global expectations of modernity - expressing security, order, and economic success in vibrant, exciting, safe, places, 'open for business' - tend to impact on the quality of life of inhabitants and most negatively on poor and marginal populations (Broudehoux 2015). Ahead of the 2014 FIFA World Cup and the 2016 Olympic and Paralympic Games in Rio de Janeiro for example, campaigners have identified concerns over the rights of children, workers, women, the disabled, LGBT, marginal populations, the socially excluded, and the environment (ANCOP 2014; see also, Horne and Silvestre 2015). Issues surrounding rights of access to facilities built at public expense, the removal of poor communities from housing and evictions, have created struggles over whom or what is (made) visible.

Legacy

The question of developing a legacy through hosting an Olympic Games or other sports mega-event was, until recently, a relatively low order issue and one that was not seriously entertained until after an event had been concluded. While all cities had a general legacy vision, which was set out in bid books, no detailed operational plans were developed before the Games about how legacy would be implemented afterwards. Legacy plans were not seriously explored until after the Games had been staged when there was a diminished interest in Olympic matters. The International Olympic Committee's (IOC) interest in an Olympic city largely ceased once the Games had been staged so there was no monitoring or evaluation of post-Games legacy implementation. The concept of 'legacy' came of age in the early years of the present century as governments recognized more clearly the potential utility of hosting as a tool in achieving a range of sport and non-sport policy objectives (Cashman 
and Horne 2013). It also developed as more concern was expressed about the costs of staging the events.

It is useful to consider two distinctions with respect to legacies when considering the political implications - that they can be tangible and intangible, and also universal and selective (for further discussion see Horne 2015; Cashman and Horne 2013). It is well established that legacies related to sports mega-events can be tangible, that is related to, for example, changes in some way to the material infrastructure or economic performance of the city or nation, and intangible, that is related to, for example, emotional responses to a mega-event whether individual or collective (Preuss 2007). Tangible legacies refer to substantial and long standing changes to the urban infrastructure - the building of iconic stadia being one of the most notable when it comes to sports mega-events. The intangible legacies of sports megaevents refer predominantly to popular memories, evocations and analyses of specific moments and incidents associated with an event.

A second distinction I want to suggest when thinking about legacy is that legacies can be selective and universal. By this distinction I mean the following. Selective legacies are particular, individualist, and elitist, and tend to serve the interests of those dominating powerful political and economic positions in society. Universal legacies are communal, collectivist, and inherently democratic, available to all by virtue of being made freely accessible. A problem for sports mega-events is that they largely generate tangible legacies that are selective and intangible legacies that are universal. Selective legacies are of benefit, enjoyed, and delivered to specific individuals or interests, rather than all, and exclude those considered not eligible to receive them. As Titmuss (1974) suggested with respect to selectivism in social policy, selectivism also serves to facilitate the sovereignty of the market. Universal legacies on the other hand are those that affect, reach and are shared by all rather than specific individuals or communities. Legacies established universally to serve everybody 
might need to be financed by governments, philanthropic organizations or, exceptionally, private enterprises. Prioritising universal legacies would mean that organisers of sports megaevents would be obligated to deliver them to all without constraints. Rather than vague claims regarding legacy they would have to demonstrate a properly funded legacy management programme that continued for some years after the event. As Titmuss $(1974,39)$ suggested with respect to universalism in social policy, it is a re-distributive institutional approach; it considers welfare (that is, 'positive legacies') as a very important institution of society provided outside the market. For sports mega-events to live up to the promotional claims made for them the legacies associated with them should follow the principle of universalism and this would require greater control and regulation over FIFA, the IOC and LOCs by nonmarket actors.

The politics of legacy associated with sports mega-events is quite well illustrated by the three quotations from Lord Sebastian Coe (Figure 3), the chair of the London Organising Committee of the Olympic and Paralympic Games (LOCOG) for London 2012. Over the six years as the build up to the games took place and the event itself approached there was a clear diminishing of focus on legacy and a distancing of responsibility from delivering on it.

Insert Figure 3 Lord Coe on the 2012 Legacy Here

London's bid to stage the 2012 Summer Olympics was fashioned in the context of greater awareness of legacy (Davies 2012). In this respect London was the first true 'legacy' Olympics in so far as the IOC had not used the concept widely before and had only staged its first conference on legacy in 2002, just two years before London submitted its bid book. Since then it has become mandatory for a city to articulate at the bid stage both a vision of how the host city and country would benefit from the staging of the Games and how its 
operational plans about the realisation of legacy would be implemented. The same also applies now to other mega-events such as the Commonwealth Games and Pan American Games.

It has been suggested that one of the reasons why London won its bid in 2005 to stage the 2012 Olympic Games was that it had attractive legacy plans in key areas: sport, youth and the regeneration of a part of East London. However the actual delivery of some of the six legacy promises is proving challenging. For example, one of the promises was to inspire a new generation of young people to take part in local volunteering, cultural and physical activity' (Horne and Houlihan 2014). Six of the local authorities closest to the Olympic site in east London were designated as 'Olympic Boroughs'. It was reported in November 2014 that two of them - Newham, the municipal authority containing Stratford, where most of the 2012 Olympics took place, and Dagenham and Redbridge - had the lowest physical activity rates in the whole of England. Over 39 per cent and 38 per cent respectively of people in these Boroughs were physically inactive (Campbell 2014).

\section{Labour}

The labour involved in putting on a sports mega-event includes paid and unpaid workers; migrant workers of the global precariat who barely scrape a living wage and those on or earning less than the minimum wage; those who work on the supply chains providing equipment, clothing and footwear; as well as those selling merchandise associated with events. In addition there are the globetrotting elite professional mega-event management experts and consultants. As a result of the governance of the Olympics being increasingly exposed to market-based mechanisms for example - such as private finance initiatives, the codification of rules and service standards, and the formalisation of oversight - an 'Olympic 
“consultocracy" or "caravan" has developed (Cashman and Harris 2012) that "wanders nomadically from Games to Games' (Jennings 2012: 3).

Few researchers have looked at this aspect of sports mega-events in detail, including the terms, conditions and safety record of the occupations required (although on London 2012 see Cohen 2013). In addition to paid workers, volunteers play a major role in the delivery of the events. 70,000 'Games Makers' were trained for London 2012 (and the same number is required for Rio 2016). 12,500 'Clydesiders' helped at the Glasgow 2014 Commonwealth Games, whilst others in Glasgow were trained in customer care based on principles of the Disney Corporation (see BBC 2014). As Raco (2014, 176) suggests recent sports megaevents - including London 2012 - have been characterized by 'the prioritization of delivery over representative democracy'. As a result democratic imperatives, 'such as those around sustainability and employment rights' have been institutionally re-placed and converted into contractual requirements on firms'. Whilst London 2012 had an excellent safety record with respect to the building of the Olympic Park, in the build up to the 2014 World Cup in Brazil at least 10 construction workers died; and two drivers were killed when a flyover collapsed in Belo Horizonte just before a semi-final match in July 2014.

Since the decision to award the 2022 FIFA World Cup Finals to Qatar in 2010 concerns have been expressed about the 'kafala' sponsorship system that operates in Qatar and other Middle East countries. The system requires that migrant workers surrender their passports to their sponsors, who effectively decide if they can leave employment or not. Investigative reporting has found that several hundreds of workers on World Cup related projects have died since 2010 (Black et al. 2014). Sandra Burrow, International Trade Union Confederation (ITUC) Secretary General, stated in 2014 that 'FIFA, the athletics body IAAF, multinationals and others which are getting a free ride on the back of modern slavery in Qatar should be ashamed to be in league with a dictatorship like this' (quoted in Dorsey 2014). 
The following two quotations, both from Sepp Blatter, FIFA President, during a talk he gave at Oxford University in October 2013, allude to the work involved in putting on a World Cup, Olympics or other sports mega-event. On the one hand Blatter acknowledged that "Football has the power to build a better future...[FIFA's job is]... helping communities in need through football" (quoted in Hyde 2013b). However when challenged about the working conditions of migrant workers in Qatar preparing the ground for the 2022 World Cup finals, he also stated that "We are not the ones that can actually change it... This is not FIFA's remit" (quoted in Hyde 2013b).

Timms (2012 and n/d) discusses the way that the anti-sweat shop campaign 'Play Fair' uses the platform of the Olympics, how it has developed, and its form for 2012. Play Fair brings together a number of labour rights groups to 'use the hook, unashamedly, of the biggest sporting event in the world'. In using the Olympic Games as a platform for its protest, Play Fair is an example of how activists can mobilise or hijack for their own purposes a platform that has already been created (as great cost) by others. As pointed out by Price $(2008,86)$, this type of platform is a 'relatively unexplored vehicle for systematic communication', and the value and reach of the Olympic platform presents a very particular opportunity for those able to mobilise it. Whilst the Olympics have long been used to promote specific causes, Timms identifies three ways it can be useful for the issue of labour rights. Firstly, the garment industry represents a significant proportion of the global labour market, with over 40 million workers; including some of the poorest, least organised and protected workers, who are disproportionately women. Campaigners claim employment can involve long hours, pressure to work at unrealistic speeds, low wages, dangerous conditions, intimidation, and little access to unions (Timms n/d). Sporting goods are a high profile part of this industry, and therefore the Olympics provide a platform to coordinate campaigns and to call for industry-wide improvements. Secondly, ethical campaigning on supply chains has had some success in 
establishing responsible governance as an issue that companies need to address. Major targets have been sports related, such as Adidas, Puma and Nike, many of whom are associated with the Olympics. This has allowed Play Fair to monitor the voluntary standards companies have agreed, drawing on the weight of Olympic bodies to add pressure. Thirdly, key elements of the Olympic platform offer specific opportunities for Play Fair, and not only its global reach. Putting on an Olympic event involves systems of licensing - for merchandise, suppliers, and sponsors, and Play Fair claim that Olympic officials could significantly impact working conditions if contracts were only granted to companies meeting internationally agreed labour standards. For example, merchandising for London 2012 involved 10,000 product lines from over 60 licensees. Then there is also the Olympic ethos, with the Olympic Charter promoting positive universal principles. This is used by Play Fair to argue that some Olympic suppliers violate the Charter, due to exploitative conditions.

\section{Conclusions}

Hosting the Olympic Games (and other mega-events) is a political act; public events and institutions involving decisions over the allocation of resources have political dimensions. They require consideration of the distribution of power, struggles and who gains from the situation. The increasingly corporate character of sports mega-events leads to various civic responses to their social impacts and legacies (Giulianotti et al 2014b). Whilst security risk management differs between the World Cup and the Olympics, there are considerable opportunities for markets in security to develop around sports mega-events. This can have consequences for civil rights and concerns about the militarization of urban locations. Hyde (2013a) asks: 'if hosting an Olympics or a World Cup were even remotely likely to advance the cause of human freedom in their countries, does anyone think the likes of China and 
Qatar would be as keen to host them as they are?' In response to her question she cited FIFA Secretary General, Jérôme Valcke, who commented: “"less democracy is sometimes better for organising a World Cup"” (cited in Hyde 2013a).

Zimbalist $(2015,122)$ suggests, 'Hosting sports mega-events...tends to reinforce the existing power structure and patterns of inequality'. Sports mega-events also tend to impact negatively on poor people - through pre-event construction and the post-event 'gentrification' of locations; and the crowding out of other spending on welfare and the general redirection of scarce resources toward the priority of delivering a mega-event. The 2010 World Cup in South Africa presented several examples where the trade-off between housing projects for people in need and the building of a stadium went in favour of the latter. Profit and event delivery come before democracy and social justice leading to a variety of responses and resistances. One of the unintended legacies of hosting a World Cup is that it can lead to social mobilization - and sometimes confrontations as was witnessed in Brazil in 2013 and 2014. Some organizers have attempted the integration and incorporation of NGOS and protest groups into the planning of events. But the mobilization of people and communities affected remains one of the most unstable and unpredictable of the social legacies of hosting sports mega-events. Flyvbjerg et al (2012) argue that social scientists should investigate the 'tension points' in mega projects. I have tried to identify some of those involved with sports mega-events in this article. Other examples of 'seizing the platform' (Price 2008) will become available as protest and event coalitions and activism develop in the future (Boykoff 2011, 2014). The contemporary contestation of sports mega-events remains a continuing story. 


\section{References}

ANCOP (Articulação Nacional dos Comitês Populares da Copa) 2014. Megaeventos e Violações de Direitos Humanos no Brasil ('Mega Events and Human Rights Violations in Brazil'). Rio de Janeiro: Articulação Nacional dos Comitês Populares da Copa.

Anholt, S. 2008. "Place Branding: Is it Marketing, or Isn't it?” Place Branding and Public Diplomacy 4 (1): 1-6.

Anholt-GfK Roper 2014. "Germany knocks USA off top spot for "best nation" after 5 years" [available online at http://www.gfk.com/news-and-events/press-room/pressreleases/pages/germany-knocks-usa-off-best-nation-top-spot.aspx; last accessed 1 December 2014].

BBC 2014. "Back to Charm School”. BBC Radio World Service, 15 July [available online at http://www.bbc.co.uk/programmes/p022f0m2; last accessed 2 December 2014].

Black, D. 2014. "Megas for Strivers: The Politics of Second-Order Events" in Leveraging Legacies from Sports Mega-Events, edited by J. Grix, 13-23. Basingstoke: Palgrave Macmillan.

Black, I, Gibson, O. and Booth, R. 2014. "QQatar promises to reform labour laws after outcry over 'World Cup slaves'." The Guardian, 14 May [available online at http:/www.theguardian.com/world/2014/may/14/qatar-reform-labout-laws-outcry-worldcup-slaves; last accessed 2 December 2014].

Boykoff, J. 2014. Activism and the Olympics: Dissent at the Games in Vancouver and London New Jersey: Rutgers University Press.

Boykoff, J. 2011. "The anti-Olympics.” New Left Review 67: 41-59.

Broudehoux, A-M. 2015. 'Mega-Events, Urban Image Construction, and the Politics of Exclusion' in Mega-Events and Globalization: Capital and Spectacle in a Changing World Order, edited by R. Gruneau and J. Horne. London: Routledge.

Campbell, D. 2014. "London Olympics borough is the most physically inactive in England." The Guardian, 12 November [available online at http://www.theguardian.com/society/2014/nov/12/london-olympics-borough-mostphysically-inactive-england; last accessed 2 December 2014]. 
Cashman, R and Harris, R. 2012. The Australian Olympic Caravan from 2000 to 2012. A unique Olympic events industry. Sydney: Walla Walla Press.

Cashman, R. and Horne, J. 2013. "Managing Olympic Legacy." in Managing the Olympics, edited by in S. Frawley \& D. Adair, 50-65. London: Palgrave.

COHRE (Centre on Housing Rights and Evictions) 2007. Fair Play for Housing Rights: Megaevents, Olympic Games and Housing Rights. Geneva: Centre on Housing Rights and Evictions.

Conn, D. 2015. "Bribe upon bribe upon bribe: how Fifa and its cronies carved up football." The Guardian Sport section: 1-2, 28 May.

Davies, L. 2012. "Beyond the games: regeneration legacies and London 2012." Leisure Studies 31 (3): 309-337.

Flyvbjerg, B. 2014. "What You Should Know About Megaprojects and Why: An Overview." Project Management Journal 45 (2): 6-19.

Flyvbjerg, B., Landman, T and Schram, S. Eds. 2012. Real Social Science: Applied Phronesis. Cambridge: Cambridge University Press.

Garcia, G. 2014. “Copa do Mundo não melhorou imagem do país no exterior, aponta índice britânico.” Brazilian News: 14, 18-24 November.

Giulianotti, R., Armstrong, G., Hales, G. and Hobbs, D. 2015. "Sport Mega-Events and Public Opposition: A Sociological Study of the London 2012 Olympics." Journal of Sport and Social Issues 39 (2): 99-119.

Giulianotti, R., Armstrong, G., Hales, G. and Hobbs, D. 2014. "Global sport mega-events and the politics of mobility: the case of the London 2012 Olympics." British Journal of Sociology, [available online at http://onlinelibrary.wiley.com/doi/10.1111/14684446.12103/abstract; last accessed 16 March 2015].

Grix, J. and Houlihan, B. 2013. "Sports mega-events as part of a nation's soft power strategy: The cases of Germany (2006) and the UK (2012).” British Journal of Politics and International Relations 16 (4): 572-596. 
Gruneau, R. and Horne, J. Eds. 2015. Mega-Events and Globalization: Capital and Spectacle in a Changing World Order. London: Routledge.

Hartmann, D. 2003. Race, Culture, and the Revolt of the Black Athlete: The 1968 Olympic protests and their aftermath. Chicago: University of Chicago Press.

Henderson, S. 2010. “'Nasty Demonstrations by Negroes': The Place of the Smith-Carlos Podium Salute in the Civil Rights Movement." In Reflections on Mexico '68, edited by K. Brewster, 78-92. London: Routledge.

Horne, J. 2015. "Managing World Cup Legacy.” In Managing the World Cup, edited by S. Frawley and D. Adair, 7-25. London: Palgrave

Horne, J. 2007. “The Four Knowns of Sports Mega-Events.” Leisure Studies 26 (1): 81-96.

Horne, J. and Houlihan, B. 2014. “London 2012.” In Leveraging Legacies from Sports MegaEvents, edited by J. Grix, 107-117. Basingstoke: Palgrave Macmillan.

Horne, J. and Silvestre, G. 2015. "Brazil, the Olympics and the FIFA World Cup." in Routledge Handbook of Sport and Politics, edited by A. Bairner, J. Kelly and J. Lee. London: Routledge.

Hyde, M. 2013a. "The greatest trick Fifa ever pulled was to issue a Qatar weather warning." The Guardian, 4 October.

Hyde, M. 2013b. "Blatter must back up his World Cup blathering." The Guardian, 21 November.

Jennings, W. 2012. Olympic risks. Basingstoke: Palgrave Macmillan.

Kelso, P. 2004. "Human rights shadow over Beijing games", The Guardian, 30 August, [available online at http://www.theguardian.com/world/2004/aug/30/china.athensolympics2004; last accessed 2 December 2014].

Müller, M. 2015. "What makes an event a mega-event? Definitions and sizes." Leisure Studies [available online at: 
http://www.tandfonline.com/doi/pdf/10.1080/02614367.2014.993333; last accessed 16 March 2015].

Preuss, H. 2007. "The Conceptualisation and Measurement of Mega Sport Event Legacies." Journal of Sport \& Tourism 12: 207-228.

Preuss, H. 2004. The Economics of Staging the Olympics: A comparison of the Games 19722008. Cheltenham: Edward Elgar.

Price, M. 2008. "On Seizing the Olympic Platform" in Owning the Olympics: Narratives of the New China, edited by M. Price and D. Dayan, 86-114. Ann Arbor: University of Michigan Press.

Raco, M. 2014. "Delivering Flagship Projects in an Era of Regulatory Capitalism: State-led Privatization and the London Olympics 2012." International Journal of Urban and Regional Research 38 (1): 176-197.

Roche, M. 2000. Mega-Events and Modernity. London: Routledge.

Timms, J. 2012. "The Olympics as a platform for protest: A case study of the London 2012 'ethical' Games and the Play Fair campaign for workers' rights.” Leisure Studies 31 (3): 355372.

Timms, J. (n/d). "Using sports mega-events to improve work in global supply chains: The Olympics, PlayFair 2012 and campaigns around corporate social responsibility", [available online at http://www.bl.uk/sportandsociety/exploresocsci/businesseconomics/business/articles/globalsu pply.pdf; last accessed 2 December 2014].

Titmuss, R. 1974. Social Policy. London: Allen \& Unwin.

Watts, J. 2013. “Sepp Blatter urges Brazil protesters not to link grievances to football.“ The Guardian, 19 June [available online at:

http:/www.theguardian.com/football/2013/jun/19/sepp-blatter-brazil-football-protests; last accessed 2 December 2014].

Whitson, D. and Horne, J. 2006. "Underestimated costs and overestimated benefits? 
Comparing the impact of sports mega-events in Canada and Japan" in Sports Mega-Events:

Social Scientific Analyses of a Global Phenomenon, edited by J. Horne and W. Manzenreiter, 73-89. Oxford: Blackwell/ Sociological Review Monograph.

Worden, M. 2015. "Raising the Bar: Mega-Sporting Events and Human Rights." Human Rights Watch World Report 2015, [available online at: http://www.hrw.org/worldreport/2015/essays/raising-bar; last accessed 16 March 2015].

Zimbalist, A. 2015. Circus Maximus. The Economic Gamble Behind Hosting the Olympics and the World Cup. Washington, D.C.: Brookings Institution Press. 
Figure 1 Sports Mega-Events in the $21^{\text {st }}$ Century: $2000-2023$

\begin{tabular}{|c|c|c|c|c|c|}
\hline $\begin{array}{l}\text { Summer } \\
\text { Olympics }\end{array}$ & $\begin{array}{l}\text { Winter } \\
\text { Olympics }\end{array}$ & $\begin{array}{l}\text { FIFA } \\
\text { World } \\
\text { Cup }\end{array}$ & UEFA EURO & PAN AM Games & $\begin{array}{l}\text { Commonwealth } \\
\text { Games }\end{array}$ \\
\hline $\begin{array}{l}2000 \\
\text { Sydney }\end{array}$ & $\begin{array}{l}2002 \\
\text { Salt Lake City }\end{array}$ & $\begin{array}{l}2002 \\
\text { Japan \& } \\
\text { South } \\
\text { Korea }\end{array}$ & $\begin{array}{l}2000 \\
\text { Belgium \& } \\
\text { Netherlands }\end{array}$ & $\begin{array}{l}2003 \\
\text { Santo Domingo }\end{array}$ & $\begin{array}{l}2002 \\
\text { Manchester }\end{array}$ \\
\hline $\begin{array}{l}2004 \\
\text { Athens }\end{array}$ & $\begin{array}{l}2006 \\
\text { Torino }\end{array}$ & $\begin{array}{l}2006 \\
\text { Germany }\end{array}$ & $\begin{array}{l}2004 \\
\text { Portugal }\end{array}$ & $\begin{array}{l}2007 \\
\text { Rio de Janeiro }\end{array}$ & $\begin{array}{l}2006 \\
\text { Melbourne }\end{array}$ \\
\hline $\begin{array}{l}2008 \\
\text { Beijing }\end{array}$ & $\begin{array}{l}2010 \\
\text { Vancouver }\end{array}$ & $\begin{array}{l}2010 \\
\text { South } \\
\text { Africa }\end{array}$ & $\begin{array}{l}2008 \\
\text { Austria \& } \\
\text { Switzerland }\end{array}$ & $\begin{array}{l}2011 \\
\text { Guadalajara }\end{array}$ & $\begin{array}{l}2010 \\
\text { Delhi }\end{array}$ \\
\hline $\begin{array}{l}2012 \\
\text { London }\end{array}$ & $\begin{array}{l}2014 \\
\text { Sochi }\end{array}$ & $\begin{array}{l}2014 \\
\text { Brazil }\end{array}$ & $\begin{array}{l}2012 \\
\text { Poland \& Ukraine }\end{array}$ & $\begin{array}{l}2015 \\
\text { Toronto }\end{array}$ & $\begin{array}{l}2014 \\
\text { Glasgow }\end{array}$ \\
\hline $\begin{array}{l}2016 \\
\text { Rio de } \\
\text { Janeiro }\end{array}$ & $\begin{array}{l}2018 \\
\text { Pyeongchang }\end{array}$ & $\begin{array}{l}2018 \\
\text { Russia }\end{array}$ & $\begin{array}{l}2016 \\
\text { France }\end{array}$ & $\begin{array}{l}2019 \\
\text { Lima }\end{array}$ & $\begin{array}{l}2018 \\
\text { Gold Coast }\end{array}$ \\
\hline 2020 & 2022 & 2022 & 2020 & 2023 & 2022 \\
\hline Tokyo & $\begin{array}{l}\text { Contenders: } \\
\text { Almaty } \\
\text { (Kazakhstan), } \\
\text { Beijing } \\
\text { [Decision - } \\
\text { Kuala Lumpur, } \\
\text { July 2015]* }\end{array}$ & Qatar & $\begin{array}{l}\text { A 'Pan-Europe' } \\
\text { competition staged in } \\
\text { different countries: } \\
\text { final at Wembley } \\
\text { Stadium, London }\end{array}$ & $\begin{array}{l}\text { Possible } \\
\text { Contenders: } \\
\text { Santiago (Chile), } \\
\text { Panama City, } \\
\text { Miami (USA) } \\
\text { [Decision - 2017] }\end{array}$ & $\begin{array}{l}\text { Contender } * * \text { : } \\
\text { Durban (SA) } \\
\text { [Formal Decision - } \\
\text { November 2015] }\end{array}$ \\
\hline
\end{tabular}

*The deadline for submitting bids to the International Olympic Committee (IOC) expired in November 2013, when six cities became official contenders for hosting the Winter Olympics in 2022. However, four European cities, Norway's Oslo, Poland's Krakow, Sweden's Stockholm and Ukraine's Lviv, later withdrew.

** Edmonton (Canada) withdrew in February 2015, leaving Durban the only contender. 
Figure 2 Contentious Issues at Selected Sports Mega-Events 2008-2022

\begin{tabular}{|l|l|l|}
\hline Beijing 2008 & $\begin{array}{l}\text { Summer Olympic and } \\
\text { Paralympic Games }\end{array}$ & $\begin{array}{l}\text { Human rights and the global } \\
\text { torch relay }\end{array}$ \\
\hline London 2012 & $\begin{array}{l}\text { Summer Olympic and } \\
\text { Paralympic Games }\end{array}$ & $\begin{array}{l}\text { Disability, workers' rights, } \\
\text { displacement }\end{array}$ \\
\hline Sochi 2014 & $\begin{array}{l}\text { Winter Olympic and } \\
\text { Paralympic Games }\end{array}$ & $\begin{array}{l}\text { Homophobia, environment, } \\
\text { ethnic minority populations }\end{array}$ \\
\hline Brazil 2014 and Rio 2016 & $\begin{array}{l}\text { FIFA World Cup Finals / } \\
\text { Summer Olympic and } \\
\text { Paralympic Games }\end{array}$ & $\begin{array}{l}\text { Displacement, political } \\
\text { priorities, workers' rights, } \\
\text { environment }\end{array}$ \\
\hline Glasgow 2014 & Commonwealth Games & $\begin{array}{l}\text { Displacement, independence } \\
\text { referendum }\end{array}$ \\
\hline Russia 2018 & FIFA World Cup Finals & Workers' rights, war \\
\hline Qatar 2022 & FIFA World Cup Finals & Workers' rights, environment \\
\hline
\end{tabular}


Figure 3 Lord Coe on the London Olympics 2012 Legacy

\begin{tabular}{|c|c|}
\hline $\begin{array}{l}\text { Sebastian Coe, } \\
\text { May } 2006\end{array}$ & $\begin{array}{l}\text { 'Legacy is absolutely epicentral to the plans for } 2012 \text {. Legacy is } \\
\text { probably nine-tenths of what this process is about, not just } 16 \text { days of } \\
\text { Olympic sport' [available at: } \\
\text { http://www.theguardian.com/sport/2006/may/04/Olympics2012.politics; } \\
\text { last accessed } 25 \text { November } 2014 \text { ]. }\end{array}$ \\
\hline $\begin{array}{l}\text { Sebastian Coe, } \\
2007\end{array}$ & $\begin{array}{l}\text { '50 per cent of the organising team are working on making sure that the } \\
\text { Games are working functionally at Games time and the other } 50 \text { per } \\
\text { cent spend every working hour worrying about what it is we are going } \\
\text { to do with these facilities afterwards' (Cashman and Horne 2013, 55, } \\
\text { quoting Shirai 2008). }\end{array}$ \\
\hline $\begin{array}{l}\text { Sebastian Coe, } \\
\text { March } 2012\end{array}$ & $\begin{array}{l}\text { 'I don't want this to sound like this is not my job, but actually it isn't. } \\
\text { We created the best platform in living memory to create the } \\
\text { environment for that to happen. This begins after } 2012 \text {. We finish and } \\
\text { go off and do whatever we do' [available at: } \\
\text { http://www.theguardian.com/sport/2012/mar/09/coe-sport-england- } \\
\text { olympic-legacy; last accessed } 25 \text { November } 2014] \text {. }\end{array}$ \\
\hline
\end{tabular}

